\title{
Early Writers in Northern Communities: Ways Teachers Might View and Reflect on Writers' Representations
}

\author{
JUDY M. PARR \\ University of Auckland, New Zealand
}

\begin{abstract}
"What did I write?" is the title of a seminal book (Clay, 1975), illustrating how we can learn what children know about print, in part, from their representations. Children's writing is socially and culturally situated; play is one context shown to help develop the use of symbol systems. A framing with several lenses is designed and applied to illustrate to teachers ways to consider the samples of early writing accompanying the play of young children in remote Northern communities in Canada. There is consideration of how information could be used to inform and optimize educative actions in such learning contexts.
\end{abstract}

\section{Introduction}

This article considers some of the outcomes of opportunities for children, in centres and schools in Northern communities in Canada, to write. Writing is broadly conceptualised to include visual art, drawing and other semiotic systems. These opportunities mostly arose from specifically designed play activities. In the play of young children language is central. In considering language in play, researchers have tended to focus on oral language. But, symbol systems are also important. "The play of young children gives most to their development of productive and receptive abilities with structured symbol systems..." (Brice Heath, 2013, p. 194). Research shows that early writing behaviours improve following dramatic play activities (Ihmeideh, 2015). The notion of Rowe (2009) that children are freer to be "textual scavengers" under the guise of play is an appealing one. When playing they may be more inclined to use their hands to create representations with whatever they can find: food, lipstick or crayons, applying them to walls or other surfaces. Play may serve not only as a means of exploring roles and identities and stimulating ideas and language but also of providing the visual images for writing, perhaps in the same way as a drawing "holds" the idea while a young writer struggles to encode it. And, it seems that the feedback gained through using the hand and the gripping action with a crayon or similar, enhances mental visualising (Reiner, 2008). Significantly, the use of visual imagery is one of the self-regulation strategies linked to enhanced writing performance (Santangelo, Harris, \& Graham, 2016).

Early writing has a reasonable research base (Rowe, 2009; Tolchinsky, 2006, 2015). The majority of the work on young children's written communication has investigated the form or patterns in the marks or symbols or has looked at looked at specific skills such as writing letters of the alphabet or name writing (e.g. Clay, 1975; Both-de Vries, \& Bus, 2010). Such research has drawn primarily from cognitive and socio-cognitive traditions. From this perspective, early writing includes the idea that the scribbles and marks of young children reflect their hypotheses about print. Even young children actively create and test hypotheses about how writing works (Bissex, 1980), building important 
foundational understandings about print functions, form and content, understandings vital to later reading and writing development. Social and cultural perspectives further consider learning to write as socially situated (e.g. Brandt, \& Clinton, 2002; Gee, 2004; Lave, \& Wenger, 1991; Street, 2003). Children learn, for example, about the writing that is part of their homes, communities, and classrooms. It is about social participation as children learn, from the perspective of the social position they occupy, about the practices of their communities with respect to writing. In addition to viewing the child as producing writing that is culturally and socially situated, recent trends view the young child writer as producing writing that is more semiotically complex (Rowe, 2009). These are ideas that teachers, particularly of children who are linguistically and culturally diverse, should consider in the writing of their children. It may be necessary to think beyond the likely restricted categories we have for considering writing and the occasions for writing: to view writing from the standpoint of particular children in particular locations.

Research suggests that children's experiences of writing in pre-school are minimal (Pelatti, Piasta, Justice, \& O'Connell, 2014), often limited to name writing and copying the alphabet (Schiller, Clements, Lara-Alecio, Sarama, \& Irby, 2013). One of the reasons suggested as to why writing is underdeveloped in early childhood settings is that we do not have a clear idea of what to look for in children's efforts to represent ideas in written form (Rowe, \& Wilson, 2015). There are few descriptions or developmental models to guide teachers. The detailed work of Rowe and Wilson (2015) is invaluable in considering how children represent the message and in exploring their understandings or intent. With the aim of providing an organizational framework for the assessment of young children's writing, Puranik and Lonigan $(2011,2014)$ examined the structure of individual and developmental differences of emergent writing and writing-related skills in preschool children (3-5-year-olds). Results from these analyses suggested that emergent writing skills are best described by three correlated but distinct factors:

1. Conceptual Knowledge: knowledge of the universal principles of print (e.g., knowledge of writing as a symbolic representational system, linearity of writing), concepts about writing (e.g., knowledge of units and means of writing), and functions of writing (e.g., purposes for which writing is used);

2. Procedural Knowledge: code-related knowledge such as alphabet knowledge, letter-writing skills, name-writing skill, and spelling, and;

3. Generative Knowledge: children's abilities to convey meaning through writing beyond the single-word level.

A close consideration of children's efforts in writing can provide educators with a window into what they and their actions are about; into their developing understandings, cognitions, and emotions. Knowing what to look for and recognizing what children are able to do in writing is important so teachers are able to reinforce and build on this. Barbara Comber and colleagues (2002) described what they called the "recognition factor..., the extent to which what children can do counts, and they can see that it counts" (p. 6, italics in original). These notions inform the focus of the current piece, namely, what teachers might notice and make of children's efforts to represent in writing and how they might respond to and use that information. The aim is to help teachers see the type of information that they could draw from their children's writing samples to find out what they can do. 
And, it aims to illustrate this by analysing a set of data from a specific group of kindergarten and Grade 1 children, about whom limited information exists, those in Northern communities in Canada.

These analyses of writing samples were not, therefore, complex. However, the broader framing or the lenses (form, function, socio-cultural influence, and social interaction) were designed to suggest how teachers, and these teachers in particular, could enrich their knowledge of their developing writers. They might do this by moving beyond the marks on the page or similar, by talking with children about their writing and by drawing on their professional observations of interaction, for example, as well as their knowledge of the children and their experiences, both within the play and more widely in their community. These lenses may help to interpret further what was actually written but, applied to reflections around the writing event, would also be informative in designing writing opportunities and specific support for writers.

The guiding questions for the paper are:

How might analyses of writing be framed to inform teachers' learning about their developing writers?

What information is obtained when the framework is applied to the writing samples of kindergarten and Grade 1 children in Northern communities?

What additional information, particularly from the context, might teachers consider and utilize?

\section{Lenses through Which to View Early Writing}

The lenses to use to consider the writing of young children are drawn from the literature. They include the idea of analysing the form of the writing, including the interweaving of different semiotic systems; exploring the purpose and function of writing by considering the intentionality of the children to convey messages, and the socio-cultural and social influences on their representations. The latter focus, the social and cultural features of writing has received limited attention but, increasingly, researchers acknowledge that learning to write is centrally related to social participation.

Form: The majority of research around young children's writing considers form. Early work, including that by Marie Clay (1975), showed the marks to be visually organized.

There have been numerous terms for describing the marks on the page and studies use different descriptors for referring to the same kind of mark. The overall finding is that there is a general progression from undifferentiated scribbles towards more conventional forms but that, at any one time, an individual child might produce a variety of forms (Sulzby, 1996). Basically, in broad terms, children progress from drawing and scribbling, to letter-like forms and letters, then to using sounds, first beginning or other salient sounds, then to attending to individual sounds in words. A typical progression, largely gleaned from Clay (1975) and Rowe's work (Rowe, \& Wilson, 2015), to describe growth in orthographic understanding is: from (a) uncontrolled scribbles, to (b) scribble units, to (c) individual stroke units, to (d) letter-like forms/personal manuscript/personal cursive/mock writing, to (e) conventional letter plus inventions, to (f) conventional letters (but no letter-sound correspondence), to (g) invented spelling (first letter, first and last, most sounds). The latter 
category indicates knowledge of what is called the alphabetic principle, understanding that oral language is made up of sounds and these can be represented in a systematic way using letters and combinations of letters. Sometimes the conventional letter strings are memorized or learned, like names.

Marks can also be considered for the principles, both conventional and unconventional, that children use to arrange the print marks. This concerns placement and directionality, whether randomly placed or linear and whether left to right or right to left as appropriate to the language; the spacing of marks; the size of the units and the quantity and variety of characters.

Researchers note that, for young children, the boundaries between different sign systems are quite fluid and they interweave (e.g. Kress, 1997; Olson, 1993). Children utilize other sign systems like oral language, gesture, gaze, body movement (especially dance), dramatic play and drama, graphics, art, and music. They are natural multi-modal communicators and Rowe (2009) suggests that childhood writing will, increasingly, be studied as one aspect of a more complex multi-modal process in which combinations of the sign systems will be seen as resources for composing.

Function: Intentionality and meaning: While the research that focussed on the marks produced by young children concluded that they were not random, the work of Harste, Woodward and Burke (1984) examined what children were thinking, what hypotheses they had when drawing, writing and reading. The results strengthened the idea of Clay (1975), Goodman (1986) and others that children intentionally use marks to express meaning. Broadly, intentionality relates to the knowledge of writing as a symbolic representational system; it is concerned with the meaning in the writing and the purposes for which writing is used.

Research is divided about whether very young children, 1-to-3-year-olds, distinguish between drawing and writing. Recent research by Lancaster (2007) with 1-and2-year-olds suggests they do not but, rather, they use the structural features of both systems. But, work with 2-year-olds by Rowe (2008) found that most of them used different marks to distinguish drawing from writing. The understandings young children have about the functions of writing and drawing is an area open for further investigation.

To find out about understandings of writing as symbolic representation and about intentionality, researchers have looked at children's strategies when they "read" their work (e.g. Rowe, \& Wilson, 2015). Coherence between image and articulated message is concerned with the extent to which the message "read" relates to the event, images, or text represented. The "reading" is examined to see whether the marks are used to "remember" the message (marks may represent physical features of message but children may "say" the message slightly differently with each "read"), or whether the marks are matched to the rhythm or length of speech stream, or whether they correspond to syllables and to phonemes, or whether there is spelling-sound correspondence between the oral message and letters written.

The kinds of messages, the topic children write about, and the complexity and register of the message have been less studied. Topic is the content of the message, what it is about but also includes descriptions of the process like "I wrote". Interestingly, some research suggests that children say "I made a w" when they create a wavy line something like a w but say "I wrote a w" when they produce the recognizable form (Harste, 
Woodward, \& Burke, 1984). Message complexity concerns the linguistic complexity of children's messages and is obtained not only from the writing but from considering the oral text generated when children "read" their messages. This aspect could include what has been also termed generative knowledge (Puranik, \& Lonigan, 2014) — which concerns the developing writer's ability to draw on and integrate different levels of language: word, phrase, sentence - into a functional writing system (Beringer et al, 1992; Beringer, \& Swanson, 1994). Register relates to the extent to which messages "read" sound more like oral or written language. The idea of differentiating oral and written language may also include knowledge of written conventions like punctuation.

Socio-cultural influences: With some exceptions (Brice Heath, 1983; Dyson, 1989) early research paid little attention to how children's efforts to use written means related to cultural patterns of homes and communities. There is evidence that the characteristics of early writing reflect those of the printed form of the language in the child's environment (Harste et al., 1984). Kress (1997) notes that children adopt and adapt culturally significant parts of complex signs when they combine mediums like paper, tools, and objects in their environment with gesture, talk, and drama. The idea that writing is a socially situated act has led a few researchers to consider how children's hypotheses and ways of writing are connected to the practice of local communities (e.g. Bloome, Katz, \& Champion, 2003; Dyson, 1993, 2003, 2010; Purcell-Gates, 1996). Bloome and colleagues (2003), for example, demonstrated that African-American pre-schoolers' written narratives often reflected community storytelling patterns. Similarly, the fact that Western rhetorical norms differ from Canadian First Nations' storytelling practices in the structure (often ending at the climax), purpose (sharing cultural beliefs), and style (collaborative) of stories or narratives has caused non-First Nations teachers to perceive First Nations students as lacking knowledge or attentiveness (Crago, Eriks-Brophy, Pesco, \& McAlpine, 1997, as cited in Malec, 2014). This foregrounds an important idea, namely, that whether children are able to utilize their existing repertoires of practice in writing and literacy more generally, is contingent on what their teachers judge as valuable or appropriate.

Social interactions and writing: Young children's writing at centre and school tends to be collaborative and this area of research explores how writing is socially mediated in interactions with others. It considers how adults scaffold young children to help them accomplish what they cannot do independently and, importantly, how teachers can open up space for dialogue about and around writing. Teachers may orchestrate certain sorts of play as a backdrop, as it were, for writing - what Shelley Stagg Peterson (2015) calls literate dramatic play-where writing is a tool that helps children to carry out their intentions in the play context or afterwards. In some cases, teachers see their role as providing experiences to build and stimulate children's use of language; in New Zealand the use of "language experience" is common. Language experience is most often described as growing from the 'organic method' of teaching and learning first articulated by Sylvia Ashton-Warner (1963). Ashton-Warner railed against the imposition of what she saw as an unnatural curriculum upon the creative energies of the child. She wrote passionately about the need for literacy to be meaningful to children, and advocated for learners' own voices to be the basis of literacy instruction: "I reach into the mind of the child, bring out a handful of the stuff I find there, and use that as our first working material" (Ashton-Warner, 1963, 
p. 15). Language experience involves orchestrating opportunities for activities that are meaningful for the child and can be used to encourage and support communication, oral and written.

Peers, too, feature in acts like talking over ideas, playing out drama, helping writers to think about the audience and to evaluate how well their texts are reaching others. Research also suggests that young writers use texts to construct social links to their peers (e.g. Dyson, 2003).

\section{What Might Be Expected in Young Children's Writing?}

The literacy knowledge that children bring to kindergarten or similar settings at around age 5 is wide-ranging and diverse, reflecting the experiences and contexts the children have encountered. Although, there is a general move towards more advanced writing forms, directional patterns, and message content across the early years (TolchinskyLandsmann, \& Levin, 1985; Puranik, \& Lonigan (2011, 2014), development is uneven. Children of the same age may show wide variation with quite different patterns and abilities; of strengths and gaps in their knowledge and skill (Dyson, 1985; Molfese et al., 2011). And, a particular child may use a variety of forms (Sulzby, 1996), for example, both conventional letters and also mock or letter-like forms. There is still much debate about whether there is a developmental ordering of children's early writing. Beyond agreeing that children's writing becomes more conventional, views about whether development is sequential and progressive or variable and individually patterned is still unclear (Rowe, \& Wilson, 2015). So, teachers need an understanding of the range (and beyond) of abilities in writing to guide them as to what to look for and also to inform the nature of goals to work towards.

While an indication of broad patterns of development can be obtained from the research literature, for teachers, indications of expectations for writing can be gained from the curriculum that applies to the children of a particular age/level of schooling and from other related descriptions like standards or progressions that education jurisdictions employ. Common to such documents are statements that describe what children might be seen to do when writing and the knowledge they might demonstrate. Interestingly, most of these statements concern form although some could be seen to relate to intention and interaction. Examples are: "Children around 6 will (at first with a high level of scaffolding as teachers help them to):

Form: form upper case and lower case letters and numerals accurately; write from left to right and leave spaces between words; say, hear, and record the predominant (initial, final, and some medial) sounds in words they want to write; attempt to transfer words from their oral language or reading to their writing (using phoneme-grapheme relationships) or from the sounds in their known writing words; use some key personal vocabulary and simple, high-frequency words (from visual memory); write several sentences (including some compound sentences with simple conjunctions); attempt to use capital letters and full stops as they develop understanding of a sentence.

Intention: hold an idea long enough in their head to record it; reread what they write. Social interaction: write simple texts including an idea, response, opinion or 
question; plan for writing using talk, pictures or text; and use resources such as word walls and peers.

\section{Applying the Lenses to View (and Reflect on) Young Children's Writing}

\section{The Contexts and Data}

The contexts, the socio-spatial nature of where the writing happened and the nature of the literacy event are important to describe. The characteristics of the setting are likely to impact on what the children represent and how they choose to represent it. Writing is shaped and produced through spaces and materials that are to hand (Kress, 1997). The way in which the teacher organizes, for example, for play and learning may both facilitate and constrain opportunities for development (Valsiner, 1997). The play space, the materials (tools and objects) available, the opportunities for talk and the nature of that talk, all help to position the children as writers and to give messages about writing and what is valued.

Teacher's reflection on writing opportunities should consider: How does this context (play or special learning-to-write event) allow children both to use and expand what they know about writing (consider the space, the tools and objects present, and their history or valence, and the access to these)? What roles are open to children and what agency do they have?

The data in this article are drawn from centres and kindergartens that are part of the NOW Play project, whose goals are to support young children's oral language and writing through play and to build teaching capacity in rural Northern communities. Three Indigenous Northern communities in Ontario provided data from kindergarten and Grade 1 children; children are four years old when they enter junior kindergarten, five years old when starting senior kindergarten and six years old when entering Grade 1. In addition, three kindergarten classrooms in a northern Alberta school division whose children are five years old at entry, and were of European descent, also provided data.

All sets of data have some detail of the context and examples of the representations. The teachers in the NOW Play project use iPods (either set up near the dramatic play centres or in parts of the room where children play with blocks or other materials) to record students' play interactions. The transcriptions of these are used at collaborative action research meetings that take place in the teachers' schools. Of the six contexts, at the time of analysis, for two there was a transcript of the talk around the representations; there were videos from three and for one an image of the play scene. These were viewed and read but used largely to amplify descriptions of the contexts; they were not analysed systematically. In total, there were over $100(\mathrm{~N}=103)$ samples (a sample was a page) of writing (also recorded on iPods) to analyse although it may be, in isolated cases, that some children were responsible for more than one. For example, there were two folktales read to the children in one context and some children may have produced a sample for the first one, "Billy Goats Gruff" and for the second, "Jack and the Beanstalk". Also, the context data do not record necessarily the teacher's exact invitation to the children to represent their experiences. With many drawings (with no writing) produced in response to the folk tales, these representations were somewhat problematic to interpret without knowing more precisely what the teacher said in inviting the children to 'write'.

Mostly the writing tasks arose out of play and could be considered as a naturally occurring classroom writing event in the sense that children were not asked to write from dictation 
or write a caption for a given image (although many did the latter, spontaneously captioning their drawing) or respond by writing in a particular, specified genre (save the retelling of the folk tale and, perhaps, the labelling activity in the Sign Company).

1. Blocks and stories: Grade 1 Indigenous children (ages 6-7) created stories as part of their play and then captured their play and narrative in written form. The children first played in small groups, talking as they collaboratively built with blocks. Following this play, they were asked to write stories about their play and/or the narratives they created as they played.

Data: $\bullet 4$ collaborative writing samples $\bullet 1$ transcript of three children playing, then writing

2. Camping play: Centre Kindergarten children (ages 5-6) played in small groups in the camping-themed dramatic play centre. The teacher arranged for the children explore the centre during parts of the day, and then later grouped them for discussions about camping. In the following week, the children wrote about what camping means to them.

Data: $\bullet 23$ writing samples $\bullet$ Image of camping play centre and materials

3. Dress up play: Kindergarten children (ages 5-6) played in a dress up dramatic play centre (complete with mirror), trying on clothes and taking on family and other reallife and imaginary roles. The teacher introduced some writing materials into the centre for the children to record descriptions of what they looked like in the different costumes.

The video series shows four ( 2 girls and 2 boys) kindergarten students (ages 5-6) in the play house and dress-up centre. The students enact a storyline of defending the house from a zombie attack. This results in demonstrations of parallel talk and collaborative talk.

Data: $\bullet 18$ writing samples $\bullet 5$ short videos (total of 4:01 minutes) $\bullet 1$ transcript of video dialogue

4. Milk castle: Kindergarten children (ages 5-6) brought in empty milk cartons and, with the teachers' help, constructed a large castle in the classroom. The children used this castle as a dramatic play and dress-up centre and created signs that they posted on the side of the castle. The video shows three kindergarten students (ages 5-6; 2 girls and 1 boy) playing in the play castle created from collected milk cartons fastened together. The children put on dress-up clothes and use props such as a wooden toy cradle and dolls to create a narrative of their own making. While sharing accessories and outfits for both the dolls and themselves, they work together as well as collaborate (most of the time) to keep the story going.

Data: $\bullet 6$ writing samples $\bullet 2$ videos (3:35 and 3:55 minutes) $\bullet 1$ document with transcripts of dialogues 
5. Responding to folktales: Grade 1 Indigenous children (ages 6-7) listened to the story "The Three Billy Goats Gruff". During the week, the teacher reread the story and the children participated verbally, and with actions and gestures. They created masks in the drama centre for their enactments, and later were asked to write the story or create a new version. This process was repeated with "Jack and the Beanstalk".

Data: • 17 writing samples from "The Three Billy Goats Gruff" 4 student-made books from "Jack and the Beanstalk".

6. Sign company: Grade 1 Indigenous children (ages 6-7) became part of a classroom "sign company" where they took on roles, created signs to label important classroom items and places, and created messages for their peers around the classroom and school. The Grade 1 students also worked with the Kindergarten (ages 5-6) classroom down the hall, where students were implementing their own version of sign making.

\section{Data: $\bullet 6$ writing samples}

\section{Analyses: Questions Guiding "Noticing" and "Reflections" from the Data}

"It's all about the questions" is the conclusion of Deborah Rowe (2010, p. 134) after reviewing seminal and current research on young children's writing. This is because, as she notes, questions create particular kinds of spaces for observing and analysing young children's literacy activities. While her reference was to research questions, the observation applies equally to the questions teachers might ask of the evidence they have. The author of this piece, who has expertise in writing, particularly teaching and assessing writing, has been an international collaborator since the beginning of the NOW Play project. But, as author, I have not been fortunate enough to visit the settings or interact with the children in these settings. So, what is "noticed" and "made" of the representations is seen through my particular lenses. Such lenses are formed not only by research knowledge about development and writing but by experience and knowledge of young children and their learning experiences in my own context. Arguably, the data and subsequent interpretations are not as rich as those which could be gleaned by an inquiring and reflective teacher who is able, over an extended period, to engage with the children concerned, not only observing but talking with them (using some of questions following, for example) and learning from such, reflecting on what s/he has noticed. This limitation needs to be borne in mind; the one small advantage perhaps is that the questions that occur to me may help to cue teacher inquiry. Similarly, in the discussion, I bring a lens from researching, and working collaboratively with teachers, in a bi-cultural, and now highly multi-cultural, nation.

Following, we consider potential questions teachers might ask about children's writing but, as noted above (under Contexts and Data), questions should also be asked of the children and about the environment in which the writing was produced.

Intentionality: The aim is to find evidence of the extent to which the children understand that their representations are intended to serve a communicative purpose, to convey a message. 
- Consider the response to your asking children to read what their piece says or tell you what it says. Also consider what children may spontaneously tell you about the representation and its message.

\begin{tabular}{|ll|}
\hline Description & What child says/does \\
\hline Marks-no interpretation & $\begin{array}{l}\text { Unable to "read or tell" (Can't/don't } \\
\text { know); unintelligible; gestures }\end{array}$ \\
Has concept of sign & $\begin{array}{l}\text { Writes, draws but no clear idea of } \\
\text { message (may ask you "What did I } \\
\text { write?") }\end{array}$ \\
& $\begin{array}{l}\text { No apparent letter-sound correspondence } \\
\text { or matching of speech units to marks }\end{array}$ \\
$\begin{array}{l}\text { Message intended-no conventional } \\
\text { correspondence }\end{array}$ & $\begin{array}{l}\text { Reads message and matches voice or } \\
\text { finger pointing to specific marks. Next } \\
\text { print-speech match or letter-sound } \\
\text { correspondence }\end{array}$ \\
& $\begin{array}{l}\text { step is attempt at letter sound } \\
\text { correspondence (has chosen a letter with } \\
\text { the purpose of matching to sound) }\end{array}$ \\
\hline
\end{tabular}

Rowe \& Wilson (2015)

In the latter categories especially, you might also consider the content of the message conveyed orally in terms of what it tells you about what is important to the child. How complex is the message (a word, a phrase, a sentence, or several sentences)? Also, does the child "tell" the message using the style of oral language or are there indications that the child knows that written language is somehow different to speaking?

Form (and use of different semiotic systems): The aim is to understand how children represent the message.

\begin{tabular}{|c|c|}
\hline "Category" & Description \\
\hline Mock letters & $\begin{array}{l}\text { Letter-like forms (combinations of strokes within same } \\
\text { unit or a "run" of loops or zigzags) }\end{array}$ \\
\hline $\begin{array}{l}\text { Combination of conventional } \\
\text { letters and invented letters }\end{array}$ & One recognizable letter (may be upside down etc.) \\
\hline $\begin{array}{l}\text { Conventional letters (no } \\
\text { spelling-sound } \\
\text { correspondence) }\end{array}$ & $\begin{array}{l}\text { All recognizable as letters but do not correspond to } \\
\text { intended message }\end{array}$ \\
\hline $\begin{array}{l}\text { Conventional letters } \\
\text { (memorized) }\end{array}$ & Name writing or known phrase \\
\hline Invented spelling (part) & $\begin{array}{l}\text { First sound represented (Note: may not use the } \\
\text { conventional letter) or first and last (leaves out many } \\
\text { sounds in message and may have random letters) }\end{array}$ \\
\hline Invented spelling (most) & $\begin{array}{l}\text { Most sounds in syllable or word in message are } \\
\text { represented (letter choices may not be conventionally } \\
\text { correct) }\end{array}$ \\
\hline
\end{tabular}

Rowe and Wilson (2015) 
Also, for younger children, consider the direction of the marks: (a) Linear but not conventional (i.e., may go right to left or top to bottom); (b) Linear and left to right first line, then unconventional; (c) Conventional placement.

Other considerations are spacing between "words" (units), the size of the letters or words and the variety of characters (letters and mock letters).

Finally, what media are used to convey the message and how have children integrated multiple sign systems?

Socio-cultural influence: Consider whether ways of writing (e.g. structure) may be drawn from the children's cultural backgrounds. What does the message content (including the drawing) tell you about the experiences of the child (in classroom, home, and community)? Do the tools chosen to represent the message (e.g. drawings, "carvings") relate to socio-cultural experiences?

Social interactions: Is there evidence, for example in the dialogue of the play, of generating material (ideas or vocabulary) for writing through interactions with others? How are children positioning themselves in the writing they produce? Do children perform their writing for others; share their writing with others?

\section{Diversity and Range in Performance}

\section{Findings: Analysis of Writing Samples}

What was most noticeable from the analysis of the representations was the range of knowledge about writing both within an age grouping (5-6 or 6-7 years) and amongst children at the same centre. The Camping context is a very good example. The samples show a 5-6 year old who presents a very abstract (that is, unrecognizable without the scribe's labels) representation of the footprints of Big Foot and of a car; to a child who is able to draw a recognizable, stick-figure-inhabited, relevant scene; to a child who draws, then adds scribbles, wavy lines, and marks that look suspiciously like letters (o, e, and t, or a plus sign); to a child who draws and adds random letters that appear to have no spellingsound correspondence; to children who write (perhaps copying) the word camping or a similar, single word, sometimes with other seemingly random letters; to children who write a sentence "I'm fishing with my family" (although this sentence had unconventional placement of words!) or "Camping with family" which had no spaces between words or "We are fishing", and, finally, to a child who writes a novel and correct sentence, "A squirrel jumped into my boot" (or is it boat because I am bringing a cultural frame of reference? We call the car storage a boot, while North Americans call it a trunk!). Similarly, there were samples from children aged 6-7 which suggested that a small number can barely draw more than a very basic representation, to children who can write more than one sentence and also write a compound sentence using simple conjunctions. These data from the children in Northern communities suggests the diversity and range of their writing is comparable to that reported in the literature.

\section{Intent}

Regarding whether the children understood that their representations were intended to serve a communicative purpose/convey a message to others, some considerable inference was required given there was generally only the representation as evidence. For 
example, where a drawing related to the context of the play or story, it is clear that children intend to portray the play or story they had been involved with. However, what is not clear is whether they were intending to communicate ideas to others, to create a message for others. Just under $20 \%$ of 6-7-year-olds' samples were classified as "unclear communicative intent" in that it was not possible to discern an intent to communicate. The issue is that there may well have been one; information about intent is best obtained as teachers talk with children about their writing. The comparable extent for 5-6-year-olds was $30 \%$ (14 of 47 samples). This difference is likely either because the older children employed more letter or letter-like forms or were able to represent the play or story context more readily in recognizable drawing form, which could be taken to suggest the desire to share something others would relate to.

\section{Form}

Around half of the samples (27) from the older groups of children had no letters or letter-like forms: they were drawings. This may have been a function of the "instructions" but this is unknown. Although an individual child may, over different occasions, produce a variety of forms, this is a quite a high proportion, given widespread expectations of curricula that 6-year-olds will be able to form letters and write some words. Of those who produced letters or letter-like forms, about half of the children used mock letters or a combination of mock and recognizable letters. The other half of those who actually produced text (16), produced invented spelling where there was a good correspondence between letters and sounds. So, once again, amongst similar aged children, there was a range of proficiency.

Of the 5-6-year-old groups, the majority produced a mixture of drawing and "text". Only six children $(13 \%)$ produced drawing only. Of those who wrote text, about a quarter produced conventional looking text but with no spelling-sound correspondence. Interestingly, just over half $(59 \%)$ of the children who wrote text, showed ability to obtain reasonably close spelling-sound correspondence in their messages. As might be expected, there seemed to be more incidences amongst this younger age group where the text appeared to be copied or scribed (five children).

The samples where there was "text" were also considered for the conventions of direction, spacing, and size. About a quarter of 5-6-year-olds showed they could use conventional direction consistently although a few started out left to right, then faltered. Regarding spacing, about $13 \%$ had grasped the idea of spacing while the rest tended not to indicate word boundaries or the spacing between letters was quite uneven. Size of letters, too, was something they were still gaining control over. For two-thirds of the younger children, the size was unconventional.

The transcript (Blocks and Stories, 6-7-year-olds) shows children know about aspects of form like linearity and size ("I stay in the lines" notes James). Of the 6-7-yearolds who produced text, $85 \%$ of them could write text appropriately, direction-wise. They were slightly less in control of spacing with $57 \%$ employing conventional spacing while, for size, around $78 \%$ had letters of reasonable size.

Finally, the texts were considered for their extent. For the 5-6-year-olds just over half of the texts (that is samples that had recognizable writing) were single word texts, while just under half produced a single sentence. By contrast, only around a quarter of 67 -year-olds wrote only a single word. The majority of students aged 6-7 who produced 
texts, were writing a sentence or sentences, with half of them producing one than one sentence or a compound sentence.

\section{Socio-cultural influence}

The Blocks and Stories narratives (Indigenous children) showed evidence of drawing on different histories or experiences. While one group wrote about moose hunting - a community practice - another drew on themes of bad guys and parties, likely from television viewing. Children readily juxtapose the traditional with the modern and fantasy with reality. In the transcript from Blocks and Stories, Alexandra and Cara are building tepees (to be in a movie it seems) and there are cows but, within this setting, Cara has a golden car and there is reference to the house security system (which appears to get stolen). The tepees appear to morph into a castle with a moat. Later we learn the castle is made of ice-cream. The transcript records children referring to films (Frozen and Jungle Book 2) which they may well draw on for ideas.

The camping representations suggest that children have very different notions about what is involved in camping. Some associate it with large recreational vehicles and others think of more modest forms like tenting. The former representation shows a decided North American cultural influence; children in Australia and New Zealand may be more likely to draw a tent and a bar-b-que! Likewise, the rescue portrayed in one of the Camping context drawings, with the text "to the rescue," involved four helicopters in formation, an image perhaps garnered from television action drama as it is unlikely in a real life scenario.

\section{Social interactions}

What was noticeable was that where there was a clear instance of collaborative writing (Blocks and Stories), the writing was of a different order to that of the individual samples from children of the same age group. It is not clear the extent to which an adult was part of this collaboration, although the children clearly scribed. The transcript from one group suggests the adult did not "supply" encodings.

The dramatic play, the talk, and the text reading that preceded the writing in each context provide stimulus for writing (and drawing ideas) although often the writing stimulates new ideas. The camping discussion around water introduced by the teacher clearly summoned up memories for the children of fishing and boating.

\section{Discussion: Using Reflection on the Data for Optimizing Learning and Development}

Early experiences and development in literacy, including writing, are vital for later literacy development. This section considers some examples of how information gleaned from a consideration of, and reflection on, writing samples and contexts could be used to inform and optimize educative actions in the NOW Play learning contexts.

The variability, the range, even at a young age, in children's understandings about writing in any particular setting is important to consider. A major concern is that those who are not within the range of what might be expected, if they continue on the same trajectory, will fall further and further behind. Expert teachers design ways in which they can support children at all levels within any planned activity by involving them differently and providing varying levels of support. While keeping the broad ultimate goals or outcomes for language and literacy clearly in view, it is possible for children to take different paths, building on their strengths and pursuing their interests. 
Sociocultural theory draws attention to ways that interactions among people and between people and artefacts are structured. For example, Valsiner's (1997) theory of 'bounded indeterminacy' emphasised that children's development is shaped through "the organisation of person-environment relationships in everyday actions" (p. 169). According to this frame, the environment is structured through boundaries, set up by other people, in the current case, teachers, which create 'zones' within which children develop. Valsiner identified three zones: the Zone of Free Movement (ZFM), the Zone of Promoted Action (ZPA) and the Zone of Proximal Development (ZPD). Through the interaction of the constraints set up by others (ZFM) and the actions that are promoted (ZPA), children can develop in ways that are within their ZPD. In this way, development can be characterised as channelled: allowing for free movement, but within constraints imposed by what is allowed and what is promoted (McNaughton, Phillips, \& MacDonald, 2000).

This, channelling, is a significant idea to think about in relation to the current data. As the orchestrators of activities, teachers in the NOW Play project might reflect on how, in dramatic play or other play activities or when using books or other common classroom events, they are optimally designing learning opportunities and incorporating specific activities and structures to help move each child to the next level of understanding. Research shows that teachers of young children, when selecting texts to read, acknowledge criteria like word difficulty and frequency; they also include criteria, such as concept difficulty and considerations such as the prior knowledge and interests of the children (Fitzgerald, Hiebert, Bowen, Relyea-Kim, Kung, \& Elmore, 2015). Teachers chose texts that fit these criteria when identifying stimuli for children's writing. The writing samples from children from Indigenous communities included the re-telling and representation of folk tales from Anglo-Canadian culture (e.g., "Three Billy Goats Gruff" and "Jack and the Beanstalk"). The individual samples produced were highly variable; the collaborative "books" written by the Indigenous children showed many quite sophisticated understandings. Reflecting on this and drawing from the theory outlined above, I thought more about the texts read to the children as a precursor to writing, and features of the context in which the samples were produced.

While the teachers selected materials that they felt would meet particular learning needs (Saul, \& Diekman, 2005), they also may have considered how to build on the familiar as well as unlock the unfamiliar (McNaughton, 2002). For example, they may have considered how the folktales built on the Indigenous children's prior knowledge and interest.

Indigenous cultures are rich in their own folktales which may include not only different content and different textual structures but also these folktales are likely to represent rich historical material and cultural traditions and maxims (in the same vein as the 'moral' learning to be taken from "Jack and the Beanstalk"). When teaching students from diverse backgrounds, responsive teaching contexts include the element of cultural responsiveness. While the term might be operationalised in various ways, central is the acknowledgement of students' cultural identity, values and language. Teachers could also consider the kinds of prior experiences that 5-6 year-old Canadian children would have had with play contexts, such as the castle that the class built with milk cartons in one NOW Play context. The teacher's knowledge of the children's out-of-school literacies, such as those from television or pictures in books, could guide the narratives created through the 
play within the classroom castle. Moje, Ciechanowski, Kramer, Ellis, Carillo and Collazo (2004) argue for the learning potential of integrating these funds of knowledge.

There is a tension between the desire to support learning through building on the familiar, prior knowledge and the wish to extend horizons and challenge and excite children with new material. In a recent study of teacher text choice for Pasifika children (Jesson, \& Parr, in press), we found that many primary teachers favoured texts that children could connect with; texts in which children saw something of themselves and their lives reflected-mirrors (Bishop, 1990). But one teacher in our research reminded the focus group that she also selected texts that supported an expanded view of the world, as window texts, including content in texts that was not commonly known to the learners. The teacher expressed the choice as "a two-way thing. Ok, you can make a connection [with the text] but, hold on, I want to broaden your experiences too", a sentiment with which others in the group agreed. This notion of broadening experiences, expanding a child's view of the world, may well have been the foremost aim when teachers in the NOW Play project chose activities and experiences to stimulate writing. These are complex matters that need to be weighed when a teacher is selecting not just texts, but other material to stimulate literacy learning, in this case, writing.

Further, I reflected more broadly on other aspects of the channelling in this activity of writing. We know that the engagement of children in writing is enhanced when it is purposeful; when they have some element of choice in how they engage in writing and what they write about and with whom. In my context, designing communicative tasks that allow for tuakanalteina pairings (more expert helping less expert, or older helping younger), providing familiar, comfortable contexts for Maori and Pasifika learners to retrieve, practice and generate vocabulary, develop fluency and build accuracy in writing is important (Si'ilata, 2014). I wondered whether the more sophisticated collaborative samples (in both Blocks and Stories and Folk Tales) were related to working in a way with which the children were most comfortable. This has implications for the teacher in structuring then supporting children's engagement in the activities.

While one aspect of supporting children's development as writers is in orchestrating the activity, the other is to utilize representations in the writing samples (together with the talk, including children's responses to inquiry as they write), as formative information for teacher's specifically designed responses. From the evidence, a large number of the NOW Play children are readily able to produce letters and letter-like forms. The goals for these children, from looking at likely usual progressions (some illustrated in the tables in this article), might be to represent salient or beginning sounds in words and to make stronger connections between print and sound. Any competent Grade 1 teacher knows that drawing attention to the connection between the letter and sound can be accomplished in a number of ways - perhaps by pointing out words in a message that begin with the same sound, asking children to verbalise what they are going to write and to tell you what sounds they hear and so on. In their article, "How do I write...?", Cabell, Tortorelli and Gerde (2013) have a table with suggestions for scaffolding young children's writing using individualized strategies. I particularly like the description of how Marvin is playing doctor in a dramatic play centre and signing prescriptions (interesting to note that Marvin's idea of key aspects of a doctor or healer's role is likely to be socio-culturally determined!) for his peers. Each prescription has his name, MAV, and some letter lookalikes. He remembers what his name looks like from memory, not from sounds, so adds additional letters as he senses the writing 
should be longer than MAV. The teacher skilfully extends this by suggesting that they write his friend's names on their prescriptions. She talks to Marvin about the letter M and that the first sound in his name is $/ \mathrm{m} /$. Together they identify others whose names start with /m/-Maria and Meredith - and he writes their names as Ms, plus some letter-like additions. With further support, Marvin is also able to identify an /s/ at the beginning of Sam and an /1/ at the beginning of Liz. He is developing an understanding of how letters represent sounds, in this case at the simplest level, the beginning of a word. Expert teachers are constantly alert to opportunities like this to seize the moment and apply instructional force. But they may also make deliberate choices. At a group level of instruction, research in my contexts shows the value of humour and of song and rap-like poetry in emphasizing sound and representation correspondences, particularly with Indigenous and Pasifika children (Jesson, \& Parr, in press; Si'ilata, 2014).

Teachers who know their children and interact with them on a daily basis are uniquely positioned to support them as developing writers; to consider not only the more obvious features of form and function but also the culturally and socially situated nature of their writing. The lenses teachers bring to bear in designing the opportunities for writing and in reflecting on the representations and other outcomes that result from particular contexts are best informed from the standpoint of particular children in particular locations.

\section{References}

Ashton-Warner, S. (1963). Teacher. London, England: Secker and Warburg.

Beringer, V. W., \& Swanson, H. L. (1994). Modifying Hayes and Flower's model of skilled writing to explain beginning and developing writing. In E. Butterfield (Ed.), Children's writing: Toward a process theory of development of skilled writing (pp. 57-81). Greenwich, CT: JAI.

Beringer, V. W., Yates, C., Cartwright, A., Rutberg, J., Remy, E., \& Abbott, R. D. (1992). Lower-level developmental skills in beginning writing. Reading and Writing, 4(3), 257-280. doi:10.1007/BF01027151

Bishop, R. S. (1990). Mirrors, windows, and sliding glass doors. Perspectives, 6(3), ixxi.

Bissex, G. (1980). Gyns at wrk: A child learns to read and write. Cambridge, MA: Harvard University Press.

Bloome, D., Katz, L., \& Champion, T. (2003). Young children's narratives and ideologies of language in classrooms. Reading and Writing Quarterly, 19, 20052223. doi:10.1080/10573560308216

Both-de Vries, A.C., \& Bus, A.G. (2010). The proper name as starting point for basic reading skills. Reading and Writing, 23(2), 173-187.

Brandt, D., \& Clinton, K. (2002). Limits of the local: Expanding perspectives on literacy as a social practice. Journal of Literacy Research, 34(3), 337-356. doi:10.1207/s15548430jlr3403_4

Brice Heath, S. (1983). Ways with words: Language, life and work in communities and classrooms. Cambridge, England: Cambridge University Press.

Brice Heath, S. (2013). The hand of play in literacy learning. In K. Hall, T. Cremin, B. Comber and L. C. Moll (Eds.), International handbook of research on children's literacy, learning, and culture (pp. 184-198). Chichester, England: WileyBlackwell. 
Cabell, S. Q., Tortorelli, L. S., \& Gerde, H. K. (2013). How do I write...? Scaffolding preschoolers' early writing skills. The Reading Teacher, 66(8), 650-659. doi:10.1002/TRTR.1173.

Clay, M. M. (1975). What did I write? Beginning writing behaviour. Portsmouth, NH: Heinemann.

Comber, B., Badger, L., Barnett, J., Nixon, H., \& Pitt, J. (2002). Literacy after the early years: A longitudinal study. Retrieved from www.myread.org/readings_literacy.htm

Dyson, A. Haas. (1985). Individual differences in emerging writing. In M. Farr (Ed.), Advances in writing research: Children's early writing development. Vol 1 (pp. 59-125). Norwood, NJ: Ablex.

Dyson, A. Haas. (1989). Multiple worlds of child writers: Friends learning to write. New York, NY: Teachers College Press.

Dyson, A. Haas. (1993). The social world of children learning to write in an urban primary school. New York, NY: Teachers College Press.

Dyson, A. Haas. (2003). The brothers and sisters learn to write: Popular literacies and school culture. New York, NY: Teachers College Press.

Dyson, A. Haas. (2010). The cultural and symbolic "begats" of child composing: Textual play and community membership. In O. N. Saracho, \& B. Spodek (Eds.), Contemporary perspectives on language and cultural diversity in early childhood education (pp. 191-211). Charlotte, NC: Information Age.

Fitzgerald, J., Hiebert, E. H., Bowen, K., Relyea-Kim, J., Kung, M., \& Elmore, J. (2015). Text complexity: Primary teachers' views. Literacy Research and Instruction, 54(1), 19-44.

Gee, J. P. (2004). Situated language and learning: A critique of traditional schooling. Abingdon, England: Routledge.

Goodman, K. (1986). What's whole in whole language? Portsmouth, NH: Heinemann.

Harste, J. C., Woodward, V. A., \& Burke, C. L. (1984). Language stories and literacy lessons. Portsmouth, NH: Heinemann.

Ihmeideh, F. (2015). The impact of dramatic play centre on promoting the development of children's early writing skills. European Early Childhood Research Journal, 23(2), 250-263. doi:10.1080/1350293X.2014.970848

Jesson, R., \& Parr, J.M. (in press). Teachers' selections of texts for Pasifika students in New Zealand primary schools. Australian Journal of Language and Literacy.

Kress, G. (1997). Before writing: Rethinking the paths to literacy. London, England: Routledge.

Lancaster, L. (2007). Representing the ways of the world. How children under three start to use syntax in graphic signs. Journal of Early Childhood Literacy, 7(3), 123154. doi:10.1177/1468798407079284

Lave, J., \& Wenger, E. (1991). Situated learning: Legitimate peripheral participation. Cambridge, England: Cambridge University Press.

Malec, A. (2014). Educational success and First Nations children. Paper for the Northern Oral Language and Writing through Play project (NOW Play). Retrieved from https://researchwebsite.files.wordpress.com/2015/01/educational-success-andfirst-nations-children-white-paper2.pdf 
McNaughton, S. (2002). Meeting of minds. Wellington, New Zealand: Learning Media Limited.

McNaughton, S., Phillips, G., \& MacDonald, S. (2000). Curriculum channels and literacy development over the first year of instruction. New Zealand Journal of Educational Studies, 35, 49-59.

Moje, E., Ciechanowski, K. M., Kramer, K., Ellis, L., Carillo, R., \& Collazo, T. (2004). Working toward third space in content area literacy: An examination of everyday funds of knowledge and discourse. Reading Research Quartely, 39(1), 38-70.

Molfese, V. J., Beswick, J. L., Jacobi-Vessels, J. L., Armstrong, N. E., Culver, B. L., White, J. M., ... Molfese, D. L. (2011). Evidence of alphabetic knowledge in writing: Connections to letter and word identification skills in preschool and kindergarten. Reading and Writing, 24(2), 133-150. doi:10.1007/s11145-0109265-8

Olson, D. R. (1993). How writing represents speech. Language, \& Communication, 13(1), 1-17. doi:10.1016/0271-5309(93)90017-H

Pelatti, C. Y., Piasta, S. B., Justice, L. M., \& O’Connell, A. (2014). Language-and literacy-learning opportunities in early childhood classrooms: Children's typical experiences and within-classroom variability. Early Childhood Research Quarterly, 29(4), 445-456. doi:10.1016/j.ecresq.2014.05.004

Peterson, S. S. (2015). Supporting primary students' writing through reading, talk, and literate dramatic play in primary classrooms. The Oklahoma Reader, 51(1), 2224.

Puranik, C. S., \& Lonigan, C. J. (2011). From scribbles to scrabble: Preschool children's developing knowledge of written language. Reading and Writing, 24(5), 567-589. doi:10.1007/s11145-009-9220-8.

Puranik, C. S., \& Lonigan, C. J. (2014). Emergent writing in pre-schoolers: Preliminary evidence for a theoretical framework. Reading Research Quarterly, 49(4), 453467.

Purcell-Gates, V. (1996). Stories, coupons, and the TV guide: Relationships between home literacy experiences and emergent literacy knowledge. Reading Research Quarterly, 31(4), 406-428.

Reiner, M. (2008). The nature and development of visualization. In J. K. Gilbert, M. Reiner, \& M. Nakhleh (Eds.), Visualization: Theory and practice in science education (pp. 25-29). New York, NY: Springer.

Rowe, D. W. (2008). Development of writing abilities in childhood. In C. Bazerman (Ed.), Handbook of research on writing (pp. 401-419). New York, NY: Lawrence Erlbaum.

Rowe, D. W. (2009). Early written communication. In R. Beard, D. Myhill, J. Riley, \& M. Nystrand (Eds.), SAGE handbook of writing development (pp. 213-231). Los Angeles, CA: Sage.

Rowe, D. W. (2010). Directions for studying early literacy as social practice. Language Arts, 88(2), 134-143.

Rowe, D. W., \& Wilson, S. J. (2015). The development of a descriptive measure of early childhood writing: Results from the Write Start! writing assessment. Journal of Literacy Research, 47(2), 245-292. doi:10.1177/1086296X15619723 
Santangelo, T., Harris, K., \& Graham, S. (2016). Self-regulation and writing: Metaanalysis of the self-regulation processes in Zimmerman, \& Risemberg's model. In C.A. MacArthur, S. Graham and J. Fitzgerald (Eds.), Handbook of writing research, $2^{\text {nd }}$ ed. (pp. 174-193). New York, NY: Guilford Press.

Saul, E., \& Diekman, D. (2005). Choosing and using information trade books. Reading Research Quarterly, 40, 502-513.

Schiller, P., Clements, D., Lara-Alecio, R., Sarama, J., \& Irby, B. J. (2013). The DLM early childhood express ${ }^{\circledR}$ (Teacher's edition). New York, NY: McGraw-Hill.

Si'ilata, R. (2014). Va'a Tele: Pasifika learners riding the success wave on linguistically and culturally responsive pedagogies. Unpublished $\mathrm{PhD}$ thesis, University of Auckland.

Street, B. (2003). What's 'new' in new literacy studies? Critical approaches to literacy in theory and practice. Current Issues in Comparative Education, 5(2), 77-91.

Sulzby, E. (1996). Roles of oral and written language as children approach conventional literacy. In C. Pontecorvo, M. Orsolini, B. Burge, \& L. D. Resnick (Eds.), Children's early text construction (pp. 25-46). Mahwah, NJ: Lawrence Erlbaum Associates.

Tolchinsky, L. (2006). The emergence of writing. In C. A. MacArthur, S. Graham, \& J. Fitzgerald (Eds.), Handbook of writing research (pp. 83-95), New York, NY: Guilford Press.

Tolchinsky, L. (2015). From text to language and back: The emergence of written language. In C. A. MacArthur, S. Graham, \& J. Fitzgerald (Eds.), Handbook of writing research ( $2^{\text {nd }}$ ed., pp. 144-193), New York, NY: Guilford Press.

Tolchinsky-Landsmann, L., \& Levin, I. (1985). Writing in preschoolers: An age-related analysis. Applied Psycholinguistics, 6(3), 319-339. doi:10.1017/S0142716400006238

Valsiner, J. (1997). Culture and the development of children's action (2 $\left.{ }^{\text {nd }} \mathrm{ed}.\right)$. Chichester, United Kingdom: Wiley.

Author Biography

Dr. Judy M. Parr is a Professor in the School of Curriculum and Pedagogy in the Faculty of Education and Social Work at the University of Auckland. Judy's research focuses on literacy, particularly writing, its development and assessment and on enhancing teacher practice in order to improve student literacy. Publications span literacy, assessment, technology, professional learning and school change. 